\title{
9. PLIOCENE BASAL DOLOMITIC AND FE-MN SEDIMENTS FROM THE TYRRHENIAN SEA, WESTERN MEDITERRANEAN, ODP LEG 1071
}

\author{
A.H.F. Robertson ${ }^{2}$
}

\begin{abstract}
In the Tyrrhenian Sea (Western Mediterranean), unusual reddish, soft to lithified, dolomitic sediments up to $45 \mathrm{~m}$ thick overlie igneous crust at the base of thick Pliocene-Quaternary deep-sea sediment successions in the Marsili (Site 650 ) and Vavilov (Site 651) basins. These sediments also overlie the Gortani Ridge, a basaltic seamount near the base of the Sardinian continental margin (Site 655 ). At both basinal sites $(650,651)$, the lowest sediments are dolomitic, with manganese oxide $(\mathrm{MnO})$ segregations. Whole-rock X-ray diffraction indicates abundant dolomite and quartz, with subordinate calcite, illite (authigenic), feldspar and minor kaolinite, chlorite, and anhydrite. Chemical analyses show strong enrichment in magnesium oxide $(\mathrm{MgO})$ and $\mathrm{MnO}$ relative to shale or deep-sea clay. $\mathrm{Mg}$ and $\mathrm{Mn}$ correlate positively and exhibit decreasing concentrations up the succession in the Marsili Basin (Site 650).

The following scenario is proposed: peridotites were exposed on the seafloor in the Vavilov Basin (Site 651) and then eroded, depositing talc in local fine-grained dolomitic sediments within the igneous basement. After local magmatism ended, the igneous basement at each site subsided rapidly (about $800 \mathrm{~m} / \mathrm{m} . \mathrm{y}$.) and was blanketed with calcareous and clay-rich oozes. During early diagenesis (from isotopic evidence; McKenzie et al., this volume) tepid fluids, of modified seawater composition, reacted with and dolomitized the overlying deep-sea sediments. At Site 651 additional Mg may have been extracted from asthenosphere peridotite cored at shallow depths (about $100 \mathrm{~m}$ ). One can hypothesize that fluids rich in $\mathrm{Mg}$ and $\mathrm{Mn}$ were flushed from the igneous basement, triggered by extensional faulting and local tilting during subsidence of the basement, and that these fluids then dolomitized the base of the overlying sediment succession. Late tectonic movements in the Vavilov Basin (Site 651) fractured already lithified dolomitic sediments and more reducing (? hydrothermal) fluids locally remobilized Fe and $\mathrm{Mn}$ and corroded dolomite crystals.
\end{abstract}

\section{INTRODUCTION}

One of the more significant discoveries of Leg 107 in the Tyrrhenian Sea (western Mediterranean) was the existence of brightly colored dolomitic, manganiferous, and ferruginous sediments directly overlying the igneous basement at three sites: (1) in the Marsili Basin (Site 650), (2) in the Vavilov Basin, and (3) on the Gortani Ridge, a seamount near the Sardinian continental margin (Site 655; Fig. 1). Similar dolomites were cored in the Tyrrhenian Sea in the Vavilov Basin during DSDP Leg 42 at Hole $373 \mathrm{~A}$. These were stratigraphically intercalated with basalt breccia and soft nannofossil ooze (Bernoulli et al., 1978). A possibility considered by the Leg 107 shipboard sedimentologists was that these sediments had precipitated from seawater, similar to the hydrothermal metalliferous oxide-sediments of modern and ancient spreading ridges (Rona et al., 1983; Rona, 1984) and ophiolites (Robertson and Boyle, 1983). However, mineralogical and chemical analyses, combined with isotopic data (McKenzie et al., this volume), now show that these unusual sediments instead were formed by low-temperature alteration of clay-rich and calcareous deep-sea sediments and are not primary seafloor chemical precipitates. This study details the occurrence and chemical composition of these sediments, in relation to comparable modern and ancient metalliferous deposits, and proposes a diagenetic model for their genesis.

\section{GEOLOGICAL SETTING}

The tectonic setting investigated by Leg 107 involves retroarc or backarc rifting above a subduction zone to form a trian-

\footnotetext{
${ }^{1}$ Kastens, K. A., Mascle, J., Auroux, C., et al., 1990. Proc. ODP, Sci. Results, 107: College Station, TX (Ocean Drilling Program).

2 Department of Geology, University of Edinburgh, West Mains Road, Edinburgh, EH9 3JW, United Kingdom.
}

gular-shaped small ocean basin largely bordered by continental crust. The locations of Site 650 in the Marsili Basin, Site 651 in the Vavilov Basin, and Site 655 on the Gortani Ridge are illustrated in Figure 1. Scientists believe that both basins formed in Pliocene time above a northwestward-dipping subduction zone, while the Gortani Ridge forms a basaltic seamount located near the base of the Sardinian margin. During backarc spreading, the Italian mainland rifted away from Sardinia and Corsica in late Miocene time, followed by the genesis of oceanic crust in the Marsili and Vavilov basins during the Pliocene. Arguments based on paleontological and paleomagnetic data suggest the Marsili Basin is upper Pliocene (about $2 \mathrm{Ma}$ ), while the Vavilov Basin to the north is apparently significantly older (?3.4-3.6 Ma) (Kastens, Mascle, Auroux, et al., 1987).

The igneous basement (Fig. 2) of the Marsili Basin (Site 650) comprises highly altered basaltic pillow lava (Beccaluva et al., this volume). Moderately to locally intense vesicularity points to high volatile-content magmas, consistent with eruption above a subduction zone in shallow water, well under 2,500 m (Jones, 1969; Dick, 1980), followed by rapid subsidence (estimated rate, $800 \mathrm{~m} / \mathrm{m}$.y.). In the Vavilov Basin (Site 651 ), below $78 \mathrm{~m}$ of basalt flows, various lithologies were cored, including basalt, doleritic sills, leucocratic intrusive rocks, metasediments, metadolerites, peridotite, and minor interbedded dolomitic fine-grained sediment (Fig. 2). The peridotite is interpreted as possible primary mantle asthenosphere that protruded to high structural levels near the continent-ocean boundary (Kastens, Mascle, Auroux, et al., 1987; Bonatti and Sayler, this volume).

Yellowish-brown fine-grained sediments also overlie basalt on the crest of the Gortani Ridge, a basaltic seamount at Sites $655 \mathrm{~A}$ and $655 \mathrm{~B}$ near the base of the Sardinian continental margin. Distinct yellowish and orangish staining persists $20 \mathrm{~m}$ into the overlying nannofossil ooze succession there (Fig. 2).

All three sites are blanketed by thick successions of Pliocene and Quaternary, deep-water pelagic, volcanogenic, and terrigenous sediments mainly deposited from suspension and by grav- 


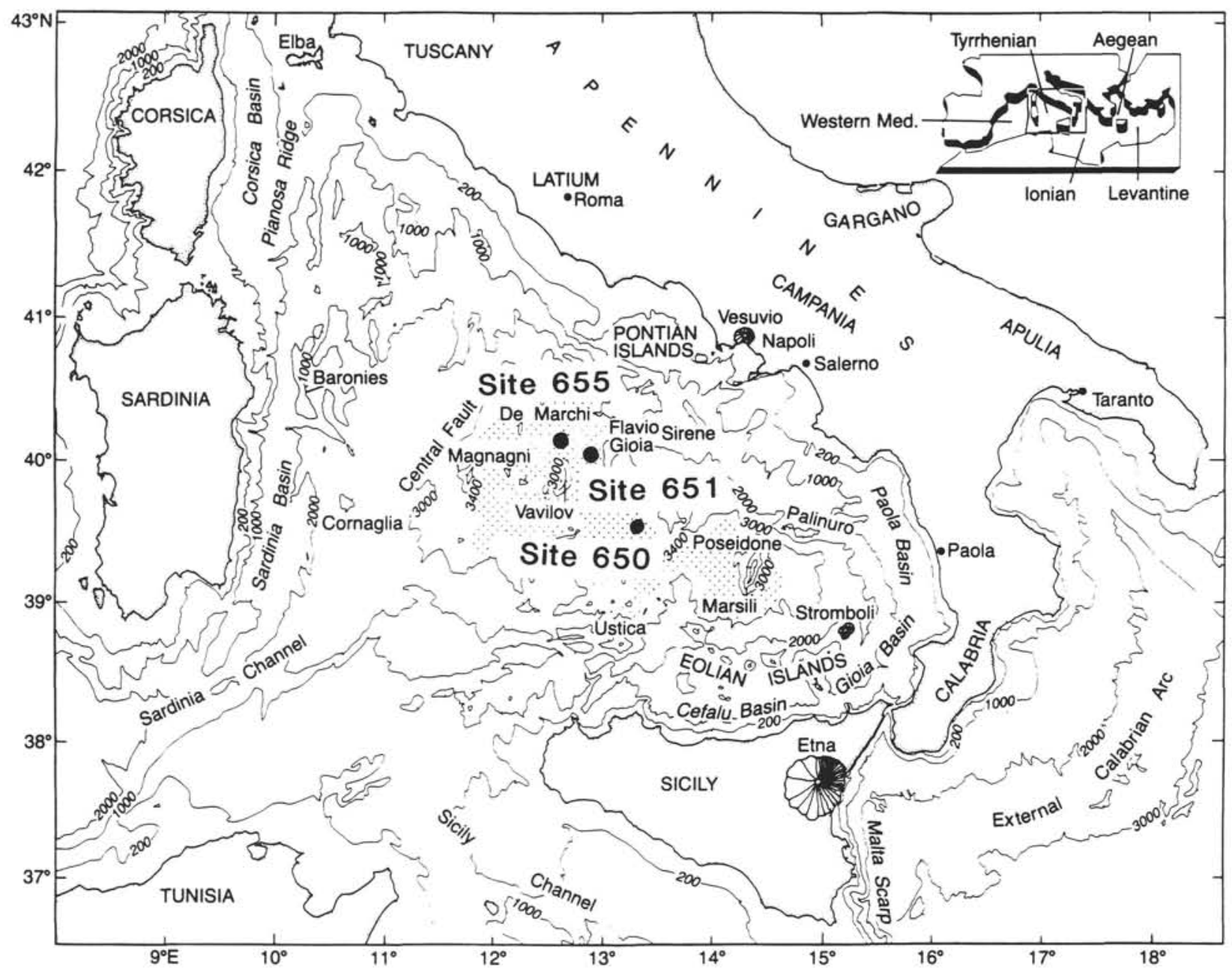

Figure 1. Bathymetric map of the Tyrrhenian Sea showing the locations of Site 650 in the Marsili Basin and Site 651 in the Vavilov Basin. Dolomitic sediments were also cored above the igneous basement at DSDP Site 373 (Leg 42A).

ity (Fig. 2). At the basinal sites $(650,651)$, thin-bedded volcaniclastic turbidites first appear near the basaltic basement.

\section{ANALYTICAL PROCEDURES}

Thirteen representative samples of the metalliferous sediments were subjected to whole-rock X-ray diffraction ( $\mathrm{CuK} \alpha$ radiation; Table 1). In addition, 34 samples of metalliferous sediments from within and above the igneous basement were selected for major- and trace-element chemical analysis using a Philips PW 1450 X-ray fluorescence spectrometer (Tables 2, 3, and 4). The major-element analysis was conducted using fused disks made with Johnson-Matthey Spectroflux 105. The calibrations used USGS and CRPG rock standards, with correction for secondary absorption. The trace elements were analyzed using pressed powder disks. Absorptions were corrected using coefficients calculated from the major-element composition. Calibrations used a wide range of international rock standards, with corrections for inter-element interference effects using spiked synthetic glass standards.

\section{DOLOMITIC SEDIMENTS OF THE MARSILI BASIN: SITE 650}

\section{Core Descriptions}

The uppermost igneous basement rocks consist of vesicular basalt (vesicles up to $5 \mathrm{~mm}$ in diameter). The stratigraphically highest igneous rocks make up a 9-cm-thick crust of basaltic glass that is directly overlain by greenish noncalcareous burrowed mudstone (lava-sediment contact in Sample 107-650A-
$66 \mathrm{R}-2,60 \mathrm{~cm}$ ). Above this, the basal metalliferous-looking sediments comprise homogeneous, burrowed, yellowish-brown to dark brown, reddish or orange, fine-grained, dolomitic sediments (Fig. 2). An oblique oxidation-reduction front runs diagonally through the basal $8 \mathrm{~cm}$ of the sediment above the basalt, which is reflected in a low $\mathrm{MnO}$ content of the sediment overlying the basalt. Similar, poorly laminated to massive, horizontally bedded, often slumped, dolomitic sediments predominate above, tending to become paler up succession (e.g., 107-650R-1, $0-118 \mathrm{~cm})$. Small greenish reduced zones appear (e.g., 107$650 \mathrm{~A}-65, \mathrm{CC}, 36 \mathrm{~cm}$ ) and become more numerous upward, with occurrences of local, up to 2.6-cm-thick, pronounced greenish reduced bands (e.g., 107-650R-65-2, 110-112 cm) that cut primary depositional lamination. Scattered pelagic foraminifer shells are visible up the succession and burrowing increases, followed by the appearance of the first coarser-grained sediment (107$650 \mathrm{~A}-65 \mathrm{R}-1,38-40 \mathrm{~cm}$ ), represented by a graded siltstone with parallel lamination. Above this, clay-rich nannofossil oozes are grayish, with occasional dark ?sulfide, and/or organic-rich layers, but with no visually detectable metal oxide.

\section{Smear Slide Data}

The stratigraphically lowest sample examined from just above the lava-sediment contact $(107-650 \mathrm{~A}-66-1,110 \mathrm{~cm})$ is composed of mainly clay and dolomite, with subordinate authigenic feldspar and traces of poorly preserved (possible) nannofossils. 


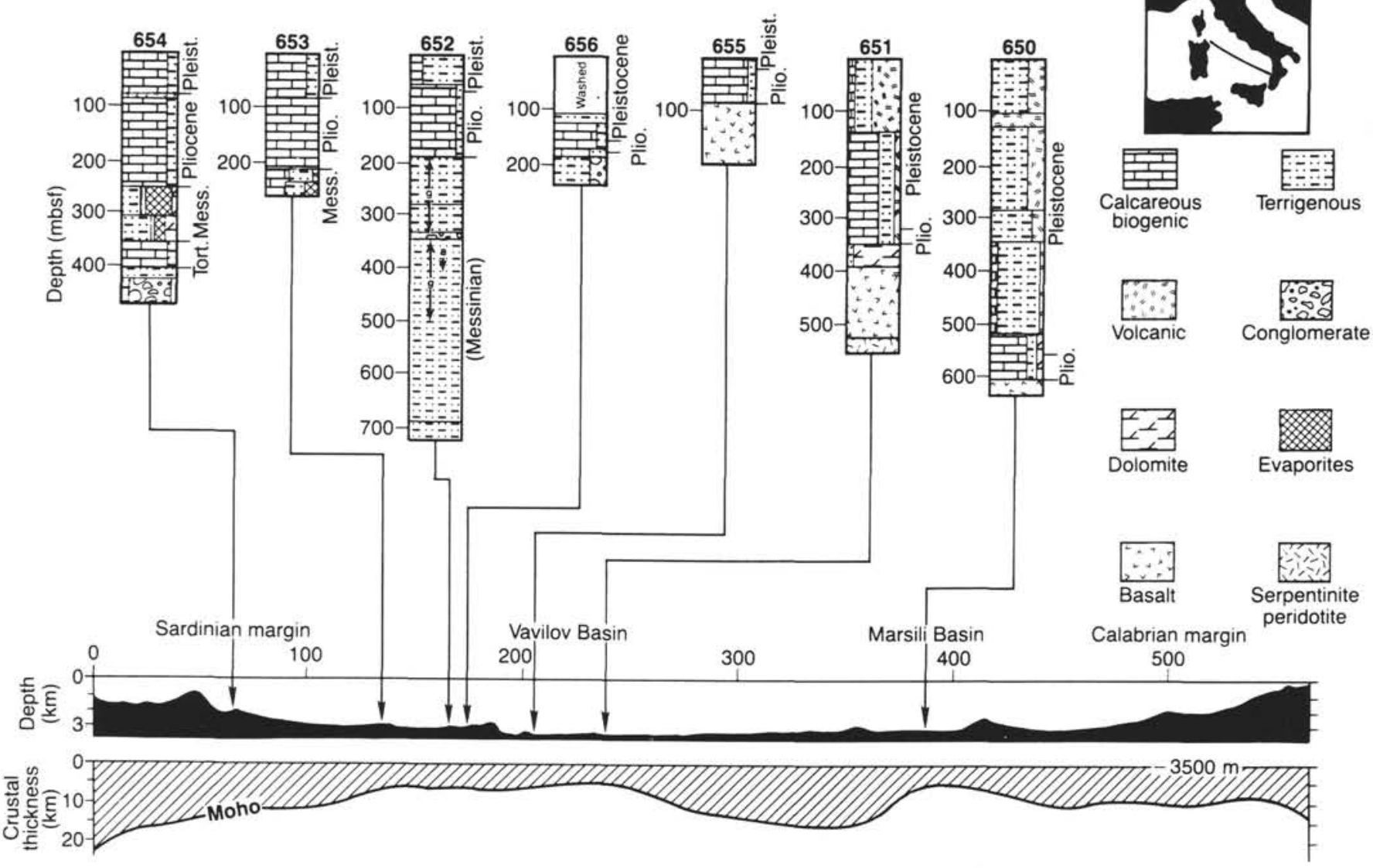

Figure 2. Simplified sedimentary logs of the Tyrrhenian Sea sites drilled during Leg 107. Metalliferous sediments were cored only at Sites 650 , 651 , and 655 .

Slightly higher up (107-650A-66R-1, $55 \mathrm{~cm})$, a sample is made up of mainly dolomite, with abundant authigenic feldspar and subordinate volcanic glass and clay minerals. Above this, in Core 107-650A-65R (107-650A-65R-2, 16, 39, and $111 \mathrm{~cm})$, smear slides contain mainly clay, nannofossils, planktonic foraminifers, rare sponge spicules, bioclasts, micrite, and carbonate spar cement. Dolomite remains are sporadically abundant up to Core 107-650A-64R (107-650A-64R-2, 37cm), about $22.5 \mathrm{~m}$ above the igneous basement.

\section{X-Ray Diffraction}

Whole rock X-ray diffraction of the basal sediments (Table 1) reveals abundant dolomite and quartz, with subordinate illite and trace abundances of feldspar, chlorite, kaolinite, and mixedlayer clays.

\section{Geochemistry}

Ten samples of the basal orange and brownish metalliferouslooking, loose to weakly lithified sediments were analyzed for major and trace elements. All the samples are rich in $\mathrm{SiO}_{2}$, $\mathrm{Al}_{2} \mathrm{O}_{3}$ and $\mathrm{K}_{2} \mathrm{O}$, reflecting the abundance of quartz and clay minerals identified by X-ray diffraction and smear slide analysis (Table 2). $\mathrm{TiO}_{2}$ values show no systematic variation and little evidence of detrital influx from the underlying volcanic basement (composed of low titanium-type basalts; Beccaluva et al., this volume). $\mathrm{CaO}$ values reflect dolomite and minor calcite abundances. Values range from $10.3 \%$ to $21.7 \%$ in the lower part of the interval analyzed, where dolomite is most abundant, in- creasing to $22.06 \%$ to $29.30 \%$ higher in the succession, where calcite increases. $\mathrm{Fe}_{2} \mathrm{O}_{3}$ values are highest in the basal sediments $(10.64 \%)$ and decrease generally up the succession to $6.27 \%$. $\mathrm{MnO}$ values are low in the greenish reduced-looking basal sediment $(0.66 \%)$, rising just above this to a maximum of $1.35 \%$, with values then decreasing upward to $0.35 \%$. $\mathrm{MnO}$ values are well above those of average shale or deep-sea clay (Turekian and Wedepohl, 1961). MgO values are enriched in the basal sediments $(7.49 \%)$, peak just above the basal sediments $(12.15 \%)$ and then wane to the general levels of the Tyrrhenian Sea sediments and deep-sea clays (2.1\%; Turekian and Wedehpohl, 1961; Fig 3). $\mathrm{P}_{2} \mathrm{O}_{5}$ values show no systematic variation. The average $\mathrm{Fe} / \mathrm{Mn}$ ratio of 0.47 contrasts with the $\mathrm{Fe} / \mathrm{Mn}$ ratios of average shale (0.005) and deep-sea clay (0.097) (Turekian and Wedepohl, 1961). Magnesium and manganese exhibit a marked positive correlation (Fig. 3), but magnesium and iron vary independently.

All the trace-element values occur in the range of deep-sea clays and exhibit no marked enrichment or major change in abundances through the succession (Table 2). The absence of a correlation between vanadium and iron is unusual, but perhaps may reflect the narrow range of $\mathrm{Fe}_{2} \mathrm{O}_{3}$ values $(5.65 \%-10.64 \%)$. Barium often correlates with $\mathrm{MnO}$, but again not in this case. However, strontium values do correspond to calcite and dolomite abundances, as predicted.

\section{Interpretation}

These sediments originally accumulated as clay-rich and calcareous deep-sea sediments without detectable influx from the 
Table 1. Results ${ }^{1}$ of whole-rock X-ray diffraction of basal dolomitic and Fe-Mn sediments from the Tyrrhenian Sea (Sites 650, 651, and 655).

\begin{tabular}{|c|c|c|c|c|}
\hline $\begin{array}{l}\text { Core, section, } \\
\text { interval }(\mathrm{cm})\end{array}$ & & $\begin{array}{l}\text { Major } \\
\text { element }\end{array}$ & $\begin{array}{l}\text { Minor } \\
\text { element }\end{array}$ & $\begin{array}{l}\text { Trace } \\
\text { element }\end{array}$ \\
\hline \multirow{4}{*}{$\begin{array}{r}12-652 \mathrm{~A}-19 \mathrm{R}-5,76-78 \\
19 \mathrm{R}-6,126-127\end{array}$} & Whole Rock & Cal. & Qtz.Ill. & Hal.Chl.Goe.Dol.Feld.Kao.Smect. \\
\hline & & Cal. & Qtz. & IIl.Hal.Chl.Feld. \\
\hline & Grey & Cal, & Qtz.Ill. & \\
\hline & Brown & Cal. & Qtz.Ill.Hal. & \\
\hline $20 \mathrm{R}-3,143-145$ & Whole Rock & Cal. & Qtz. & Goe.Hal.III.Feld. \\
\hline \multirow[t]{3}{*}{$20 \mathrm{R}-6,75-76$} & & Qtz.Dol.Cal. & Ill.Cal. & Feld.Goe. \\
\hline & Grey & Qtz.Cal. & Dol.IIl.Chl. & Feld.Smect. \\
\hline & Brown/Green & Goe. & & Hal.Ill.Smect. \\
\hline \multirow{2}{*}{$\begin{array}{l}55 \mathrm{R}-66,8-10 \\
58 \mathrm{R}-3,63-66\end{array}$} & & Qtz.Dol. & Chl.IIl. & Feld.Hal.Kaol. \\
\hline & & Qtz.Dol. & Chl.IIl.Feld. & Hal.Kaol.Smect. \\
\hline \multirow{3}{*}{$59 \mathrm{R}-1,130-132$} & Whole Rock & Qtz.Dol.Feld. & Chl.Ill. & Hem.Hal.Kaol.Anhyd.(mixed layer) \\
\hline & Grey & Qtz.Dol. & Chl.IIl. & $\begin{array}{l}\text { Kaol.Feld.Anhyd. } \\
\text { later }\end{array}$ \\
\hline & Red & Qtz.Dol. & Anhyd.Hem. & Kaol.Chl.Feld. \\
\hline \multirow[t]{2}{*}{$59 \mathrm{R}-1,136-138$} & & Qtz. & Dol.Chl.Ill. & Feld.Kaol.Hal. \\
\hline & Whole Rock & & & \\
\hline \multirow[t]{2}{*}{$112-653 \mathrm{~A}-27 \mathrm{R}-4,26-28$} & & Qtz.Hem. & Goe.Gyp. & Ill.Chl.Feld.Kaol. \\
\hline & Red & Qtz.Hem. & Chl. & Ill.Feld.Kaol. \\
\hline \multirow[t]{2}{*}{$28-1,40-42$} & White & $\begin{array}{l}\text { Gyp. } \\
\text { Otz.Gyp. }\end{array}$ & Feld.Ill. & $\begin{array}{l}\text { Qtz. } \\
\text { Chl.Kaol. }\end{array}$ \\
\hline & Whole Rock & & & \\
\hline \multirow{3}{*}{$112-654 \mathrm{~A}-26 \mathrm{R}-5,55-60$} & & Cal. & Qtz. & Feld.Ill.Dol.Goe.Hal. \\
\hline & Brown & Cal. & Qtz. & Goe.Ill.Dol.Hal. \\
\hline & White & Cal. & Qtz. & Hal.Kaol.Dol.Ill. \\
\hline $28 \mathrm{R}-3,37-40$ & & Cal.Qtz.Dol. & Ill.Chl. & Gyp.Kaol.Feld. \\
\hline \multirow[t]{2}{*}{$\begin{array}{r}112-656 \mathrm{~A}-4 \mathrm{R}-6,54-57 \\
6 \mathrm{R}-4,74-78\end{array}$} & & $\begin{array}{l}\text { Dol.Qtz. } \\
\text { Qtz. }\end{array}$ & $\begin{array}{l}\text { Ill.Kaol. } \\
\text { Dol.Cal.Hem. }\end{array}$ & $\begin{array}{l}\text { Anhyd.Hem. } \\
\text { Goe.Kaol.Chl.Feld.Hal.IIl. }\end{array}$ \\
\hline & Whole Rock & & & \\
\hline \multirow{4}{*}{$9 \mathrm{R}-2,138-139$} & & Qtz. & Dol.Hem.Goe. & Ill.Kaol.Chl.Feld \\
\hline & Red & Qtz. & Dol.Hem.Goe. & Feld.Kaol.Chl.Ill. \\
\hline & Grey & Qtz.Dol & Chl.IIl. & Smect. \\
\hline & Whole Rock & & & \\
\hline \multirow[t]{3}{*}{$9 \mathrm{R}-3,71-79$} & & Qtz. & Dol.Hem.Goe. & Chl.Kaol.IIl.Feld. \\
\hline & $\begin{array}{l}\text { Grey } \\
\text { White }\end{array}$ & Dol.Qtz. & III. & Anhyd.Chl. \\
\hline & $\begin{array}{l}\text { White } \\
\text { Red }\end{array}$ & Qtz.Dol.Hem. & Goe. & Kaol.Ill.Feld.Smect. \\
\hline 9R-6, 105-107 & $\begin{array}{l}\text { Hard bits } \\
\text { White }\end{array}$ & Qtz.Dol.Mag. & Kaol. & \\
\hline
\end{tabular}

Note: Anhyd. $=$ Anhydrite, Cal. $=$ Calcite, Chl. $=$ Chlorite, Dol. = Dolomite, Feld. $=$ Feldspar, Goe. $=$ Goethite, Gyp. = Gypsum, Hal. = Halite, Hem. = Hematite, Ill. = Illite, Kaol. = Kaolonite, Mag. = Magnesite, Smect. $=$ Smectite and mixed layer clay, Qtz. = Quartz.

1 Analyst, G. R. Angell.

underlying volcanic basement. Zirconium and rubidium contents suggest a compositionally constant influx from a terrigenous source. Slight enrichment in chromium relative to deep-sea clays (Turekian and Wedepohl, 1961) might reflect a fine-grained volcanogenic (ash) influx into the basin, as is also indicated by the smear slide analyses. Elements that are frequently enriched in hydrothermal sediments in the modern oceans (e.g., copper, zinc, nickel, and lead; e.g., Boström and Peterson, 1969; Rona, 1984 ) indicate values typical of deep-sea clays that have no enrichment. The Marsili Basin sediments are compositionally dissimilar, and a primary chemical precipitation origin is thus most unlikely.

Optical petrography and electron microscopy indicate that the dolomite is composed of well-crystallized rhombs (5-20 $\mu \mathrm{m}$ in size) (Kastens, Mascle, Auroux, et al., 1987). X-ray diffraction further indicates that the dolomite is mainly stoichiometric, or enriched in calcium, relative to magnesium ions, as noted in the Vavilov Basin from DSDP Hole 373A (Bernoulli et al., 1978). Oxygen-isotopic equilibrium temperatures for the dolomite range from 14.0 to $45.4^{\circ} \mathrm{C}$ (McKenzie et al., this volume).

\section{BASAL AND INTRABASEMENT SEDIMENTS OF VAVILOV BASIN: SITE 651}

\section{Core Description}

Altered, fine-grained carbonate sediment intercalated with the igneous basement (107-651-50R, 40-68 cm; Fig. 2) is composed of yellowish-brown to dark brown, fine-grained dolomite containing black specks and streaks, which decreases in abundance up the succession. Brecciated clasts of chilled basalt and dolomite alternate stratigraphically above this sediment (Sections $107-651 \mathrm{~A}-42 \mathrm{R}-1$ and $-42 \mathrm{R}-2$ ). The sedimentary rock clasts are composed of pale pink to light reddish-brown dolomitic breccia. Similar sediment is found within cracks in the chilled margins of glassy basalt, indicating that lava and fine-grained sediments originally were closely interbedded.

Unlike Site 651 , the depositional contact with the overlying sediments was not cored; above the last basalt fragment recovered, the succession is made up of alternations of poorly lithified, fine-grained dolomite that is varicolored (olive brown, yellowish brown), poorly lithified to moderately well lithified, with 
Table 2. Results of major- and trace-element analysis of the metalliferous and dolomitic sediments from the Marsili Basin, Site 650 .

\begin{tabular}{|c|c|c|c|c|c|c|c|c|c|c|c|c|c|c|c|c|c|c|c|c|c|c|c|c|c|c|c|c|c|}
\hline $\begin{array}{l}\text { Core, section, } \\
\text { interval }(\mathrm{cm})\end{array}$ & $\mathrm{SiO}_{2}$ & $\mathrm{Al}_{2} \mathrm{O}_{3}$ & $\mathrm{Fe}_{2} \mathrm{O}_{3}$ & $\mathrm{MgO}$ & $\mathrm{CaO}$ & $\mathrm{Na}_{2} \mathrm{O}$ & $\mathrm{K}_{2} \mathrm{O}$ & $\mathrm{TiO}_{2}$ & $\mathrm{MnO}$ & $\mathrm{P}_{2} \mathrm{O}_{5}$ & Total & LOI & V & $\mathrm{Ba}$ & $\mathrm{Sc}$ & La & $\mathrm{Nd}$ & $\mathrm{Ce}$ & $\mathrm{Cr}$ & $\mathrm{Ni}$ & $\mathrm{Cu}$ & $\mathrm{Zn}$ & $\mathrm{Pb}$ & Th & $\mathrm{Rb}$ & Sr & $\mathrm{Y}$ & $\mathrm{Zr}$ & $\mathrm{Nb}$ \\
\hline $112-650 \mathrm{~A}-63 \mathrm{R}-4,53$ & 43.26 & 15.09 & 6.27 & 3.09 & 25.94 & 1.49 & 2.49 & 0.66 & 0.58 & 0.16 & 99.03 & 21.1 & 139 & 202 & 14 & 26 & 30 & 69 & 100 & 53 & 32 & 90 & 35 & 6 & 115 & 912 & 25 & 118 & 14 \\
\hline $65 \mathrm{R}-1,118$ & 44.73 & 15.51 & 7.51 & 2.95 & 23.35 & 1.40 & 2.52 & 0.71 & 0.35 & 0.14 & 99.21 & 20.1 & 178 & 247 & 11 & 36 & 32 & 75 & 108 & 50 & 44 & 95 & 19 & 10 & 118 & 682 & 23 & 143 & 15 \\
\hline $66 \mathrm{R}-1,9$ & 42.13 & 15.02 & 5.65 & 2.66 & 29.30 & 1.55 & 2.20 & 0.63 & 0.33 & 0.14 & 99.66 & 22.5 & 136 & 199 & 9 & 30 & 29 & 72 & 102 & 55 & 40 & 107 & 35 & 6 & 114 & 849 & 24 & 113 & 14 \\
\hline $66 \mathrm{R}-1,29$ & 41.83 & 13.83 & 9.19 & 7.21 & 22.06 & 1.27 & 2.41 & 0.61 & 0.72 & 0.19 & 99.36 & 22.3 & 143 & 235 & 13 & 24 & 24 & 63 & 97 & 71 & 28 & 100 & 32 & 8 & 119 & 395 & 24 & 120 & 13 \\
\hline $66 \mathrm{R}-1,50$ & 46.71 & 15.34 & 7.47 & 8.07 & 15.97 & 1.40 & 2.79 & 0.66 & 0.83 & 0.14 & 99.42 & 19.5 & 146 & 216 & 20 & 35 & 25 & 62 & 121 & 107 & 29 & 95 & 22 & 9 & 114 & 145 & 19 & 126 & 13 \\
\hline $66 \mathrm{R}-1,70$ & 48.85 & 16.09 & 7.49 & 7.94 & 12.87 & 1.61 & 2.99 & 0.66 & 0.81 & 0.14 & 99.50 & 17.9 & 148 & 253 & 17 & 43 & 23 & 74 & 106 & 86 & 25 & 105 & 36 & 14 & 124 & 167 & 25 & 138 & 18 \\
\hline $66 \mathrm{R}-1,84$ & 43.64 & 13.69 & 7.29 & 10.60 & 17.99 & 1.34 & 2.50 & 0.61 & 1.27 & 0.13 & 99.10 & 22.5 & 157 & 240 & 16 & 36 & 31 & 82 & 112 & 83 & 27 & 108 & 33 & 12 & 130 & 246 & 26 & $\begin{array}{l}134 \\
134\end{array}$ & 16 \\
\hline $66 \mathrm{R}-1,113$ & 42.62 & 13.40 & 7.92 & 10.76 & 18.41 & 1.41 & 2.23 & 0.60 & 1.31 & 0.13 & 98.84 & 23.4 & 127 & 216 & 12 & 38 & 24 & 62 & 95 & 80 & 24 & 102 & 42 & 11 & 115 & 181 & 26 & 133 & 15 \\
\hline $66 \mathrm{R}-2,7$ & 39.60 & 12.42 & 7.86 & 12.15 & 21.74 & 1.19 & 2.28 & 0.57 & 1.35 & 0.13 & 99.33 & 25.3 & 106 & 188 & 12 & 30 & 30 & 56 & 87 & 79 & 19 & 94 & 33 & 11 & 105 & 180 & 22 & 126 & 12 \\
\hline $66 \mathrm{R}-2,28$ & 48.67 & 15.93 & 10.64 & 7.48 & 10.34 & 1.54 & 3.08 & 0.70 & 0.66 & 0.16 & 99.24 & 16.3 & & & & & & & & & & & & & & & & & \\
\hline
\end{tabular}

Note: For details of analytical procedure see the text. Major elements are in weight percent (wt \%) of oxide, and trace elements in parts per million (ppm). LOI $=$ loss on ignition (analysts: D. James and G. R. Angell).

Table 3. Results of major- and trace-element analysis of basal and intra-igneous basement metalliferous sediments from the Vavilov Basin, Site 651.

\begin{tabular}{|c|c|c|c|c|c|c|c|c|c|c|c|c|c|c|c|c|c|c|c|c|c|c|c|c|c|c|c|c|c|}
\hline $\begin{array}{l}\text { Core, section, } \\
\text { interval }(\mathrm{cm})\end{array}$ & $\mathrm{SiO}_{2}$ & $\mathrm{Al}_{2} \mathrm{O}_{3}$ & $\mathrm{Fe}_{2} \mathrm{O}_{3}$ & $\mathrm{MgO}$ & $\mathrm{CaO}$ & $\mathrm{Na}_{2} \mathrm{O}$ & $\mathrm{K}_{2} \mathrm{O}$ & $\mathrm{TiO}_{2}$ & $\mathrm{MnO}$ & $\mathrm{P}_{2} \mathrm{O}_{5}$ & Total & LOI & V & $\mathrm{Ba}$ & $\mathrm{Sc}$ & $\mathrm{La}$ & $\mathrm{Nd}$ & $\mathrm{Ce}$ & $\mathrm{Cr}$ & $\mathrm{Ni}$ & $\mathrm{Cu}$ & $\mathrm{Zn}$ & $\mathrm{Pb}$ & Th & $\mathrm{Rb}$ & $\mathrm{Sr}$ & $\mathrm{Y}$ & $\mathrm{Zr}$ & $\mathrm{Nb}$ \\
\hline \multicolumn{30}{|l|}{$112-651 \mathrm{~A}$} \\
\hline 38R-5, 31 & 42.58 & 14.00 & 5.46 & 14.23 & 17.24 & 1.26 & 2.42 & 0.62 & 0.69 & 0.11 & 98.66 & 24.1 & 114 & 285 & 18 & 34 & 36 & 76 & 91 & 68 & 95 & 97 & 38 & 14 & 114 & 114 & 25 & 126 & 15 \\
\hline $38 \mathrm{R}-5,68$ & 27.69 & 9.90 & 4.99 & 22.45 & 31.12 & 0.76 & 1.41 & 0.41 & 0.50 & 0.11 & 99.39 & 33.6 & 94 & 160 & 6 & 28 & 26 & 51 & 73 & 50 & $\$ 56$ & 69 & 26 & 8 & 79 & 127 & 20 & 81 & 10 \\
\hline $39 \mathrm{R}-1,89$ & 33.19 & 12.28 & 5.05 & 9.08 & 25.31 & 0.95 & 1.86 & 0.52 & 1.05 & 0.16 & 99.42 & 29.9 & 128 & 536 & 14 & 38 & 31 & 73 & 89 & 76 & 118 & 103 & 74 & 11 & 97 & 124 & 24 & 94 & 12 \\
\hline $39 \mathrm{R}-1,44$ & 40.60 & 14.58 & 10.59 & 12.61 & 15.99 & 1.22 & 2.45 & 0.64 & 0.26 & 0.22 & 99.21 & 22.8 & 185 & 222 & 15 & 45 & 26 & 80 & 115 & 78 & 90 & 115 & 40 & 13 & 116 & 118 & 25 & 128 & 15 \\
\hline $39 \mathrm{R}-4,11$ & 41.14 & 13.69 & 5.23 & 15.11 & 19.57 & 1.21 & 2.21 & 0.64 & 0.59 & 0.13 & 99.56 & 25.6 & 100 & . & 14 & 44 & 2 & 83 & 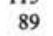 & 1 & 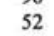 & o & 52 & 13 & 105 & & 24 & 137 & 16 \\
\hline $40 \mathrm{R}-2,80$ & 36. & 12. & 4.45 & 18.07 & 22.74 & 1.3 & 1.60 & 0.5 & 1. & & 99.40 & 28 & ic & 32 & 11 & 33 & 26 & 47 & 63 & 137 & 60 & 88 & 22 & 20 & & & & 1 & 10 \\
\hline $40 \mathrm{R}-3,84$ & 38.00 & 13.22 & 5.14 & 16.04 & 20.19 & 1.13 & 1.98 & 0.57 & 0.96 & 0.12 & 97.39 & 26.6 & 120 & 251 & 13 & 33 & 23 & 62 & 81 & 70 & 47 & 88 & 31 & 9 & 103 & 115 & 24 & 110 & 12 \\
\hline $41 \mathrm{R}-1,116$ & 46.28 & 15.18 & 6.37 & 11.49 & 14.9 & 1.3 & 2.71 & 0.6 & 0.2 & 0.16 & 99. & 20.8 & 140 & 245 & 15 & 32 & 30 & 66 & 116 & 62 & 36 & 105 & 29 & 13 & 126 & 17 & 25 & 129 & 16 \\
\hline$-3,1$ & 34 & 11 & 4.24 & 19.40 & 25.43 & 1. & 1.76 & 0.5 & 0. & & 99.35 & 30 & 108 & 179 & 11 & 24 & 28 & 52 & 86 & 55 & 35 & 82 & 37 & 10 & 97 & 114 & 23 & 97 & 12 \\
\hline$-5,1$ & 51. & 15.58 & 7.70 & 8.19 & 8.60 & 2. & 3.31 & 0.7 & 1. & 0.19 & 98.64 & 14.8 & 184 & 0 & 10 & 28 & 18 & 66 & 108 & 63 & 27 & 4048 & 83 & 8 & 89 & 195 & 15 & 88 & 10 \\
\hline $50 \mathrm{R}-1,138$ & 43.33 & 12.07 & 5.17 & 17.37 & 16.84 & 1.17 & 1.96 & 0.48 & 0.14 & 0.10 & 98.66 & 25.3 & 109 & 10 & 14 & 29 & 24 & 60 & 167 & 198 & 51 & 96 & 31 & 10 & 96 & 93 & 23 & 95 & 12 \\
\hline $50 \mathrm{R}-1,165$ & 42.12 & 12.32 & 5.33 & 16.39 & 18.71 & 1.17 & 1.72 & 0.55 & 0.37 & 0.13 & 98.85 & 25.4 & 100 & 432 & 14 & 28 & 29 & 66 & 100 & 119 & 44 & 83 & 46 & 10 & 89 & 120 & 23 & 113 & 13 \\
\hline
\end{tabular}

Note: Major elements are in weight percent (wt\%) oxide, and trace elements are in parts per million (ppm). LOI los on ignition. For details of the analytical procedure see the text (analysts: D. James and G. R. Angell).

\section{Table 4. Results of major- and trace-element analysis of basal sediments overlying the Gortani Ridge at Site 655 .}

\begin{tabular}{|c|c|c|c|c|c|c|c|c|c|c|c|c|c|c|c|c|c|c|c|c|c|c|c|c|c|c|c|c|c|}
\hline $\begin{array}{l}\text { Core, section, } \\
\text { interval }(\mathrm{cm})\end{array}$ & $\mathrm{SiO}_{2}$ & $\mathrm{Al}_{2} \mathrm{O}_{3}$ & $\mathrm{Fe}_{2} \mathrm{O}_{3}$ & $\mathrm{MgO}$ & $\mathrm{CaO}$ & $\mathrm{Na}_{2} \mathrm{O}$ & $\mathrm{K}_{2} \mathrm{O}$ & $\mathrm{TiO}_{2}$ & $\mathrm{MnO}$ & $\mathrm{P}_{2} \mathrm{O}_{5}$ & Total & LOI & $\mathrm{v}$ & $\mathrm{Ba}$ & $\mathrm{Sc}$ & La & $\mathrm{Nd}$ & $\mathrm{Ce}$ & $\mathrm{Cr}$ & $\mathrm{Ni}$ & $\mathrm{Cu}$ & $\mathrm{Zn}$ & $\mathrm{Pb}$ & Th & $\mathrm{Rb}$ & $\mathrm{Sr}$ & $\mathrm{Y}$ & $\mathrm{Zr}$ & $\mathrm{Nb}$ \\
\hline$-655 \mathrm{~A}-6 \mathrm{R}-3,81$ & 42. & 13.7 & 5.71 & 2.63 & 29 & 1.71 & 1.90 & 0.59 & 0.14 & 0.13 & 99.41 & 22.9 & 97 & 251 & 9.5 & 25 & 31 & 60 & 75 & 56 & 21 & 74 & 38 & 9 & 111 & 932 & 25 & 126 & 14 \\
\hline $8 \mathrm{R}-2,37$ & 74 & 12.95 & 11.98 & 2. & 31.14 & 1. & 0.94 & 0.55 & 0.43 & 0.3 & 98.76 & 25.0 & 89 & 129 & - & 36 & 34 & 69 & 76 & 114 & 48 & 95 & 32 & 6 & 81 & 872 & 26 & 125 & 11 \\
\hline $8 \mathrm{R}-4,66$ & 50 & 15.70 & 9.00 & 4.01 & 13 & 2 & 2.99 & 0.71 & & 0 & 99.47 & 14.8 & 128 & 279 & 13 & 18 & 19 & 52 & 62 & 72 & 78 & 96 & 14 & 11 & 102 & 486 & 19 & 142 & 11 \\
\hline 9R-4, & 5 & 10.47 & 4. & 3.14 & 48.06 & 1. & 0.67 & 0. & 0. & & 99.49 & 30.7 & 100 & 2 & & 13 & 26 & 47 & 69 & 9 & 3 & 6 & 46 & 2 & 77 & 2 & & 88 & 11 \\
\hline & 24.49 & 8.8 & 3. & 4.23 & 55. & 0 & 0. & 0 & . & . & . & 3 & 60 & i & - & 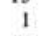 & 20 & 40 & 50 & 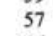 & 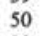 & 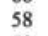 & 3 & 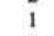 & 4 & 5 & 0 & 62 & 8 \\
\hline 9R-CC, 16 & 17.73 & 6.69 & 3.12 & 25.47 & 44.26 & 0.67 & 0.37 & 0.30 & 0.45 & 0.11 & 99.21 & 38.9 & 77 & 110 & $=$ & 15 & 28 & 44 & 38 & 56 & 29 & 58 & 60 & 5 & 46 & 265 & 16 & 52 & 7 \\
\hline
\end{tabular}

Note: Major elements are in weight percent (wt\%), and trace elements are in parts per million (ppm) (analysts: D. James and G. R. Angell). 


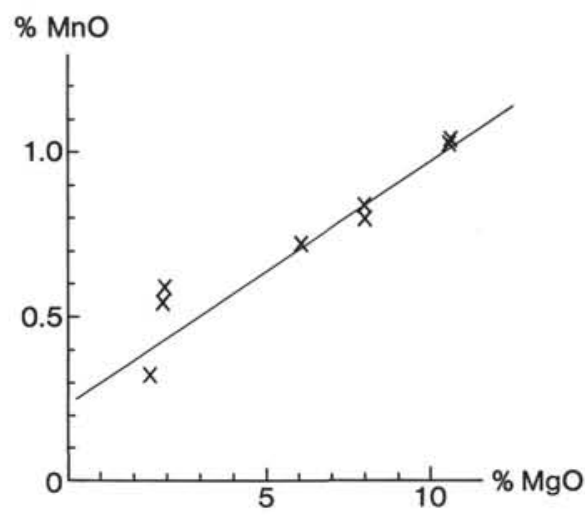

Figure 3. Variation plot of $\mathrm{MnO}$ vs. $\mathrm{MgO}$ for basal sediments at Site 650 in the Marsili Basin.

scattered dark gray diffused specks up to several millimeters in size. Several millimeter-thick layers of greenish and grayish feldspathized tuff can also be seen. Up the succession, the dolomite is moderately burrowed and varies in color from light reddish to pinkish, grayish, yellowish, reddish, brownish, and orange (PI. 1,1 Figs. 1-3). Many burrows exhibit concentrations of black $\mathrm{MnO}$ and orange limonite. Manganese dendrites are common at this level (Sample 107-651A-40R-1, $140 \mathrm{~cm}$ ), and a 3-cm-thick layer of crudely laminated crystalline $\mathrm{MnO}$ (Sample 107-651A$40 \mathrm{R}-1,62-65 \mathrm{~cm}$ ) also occurs. Shipboard visual data suggested that dolomitization may have been complex, possibly involving successive events.

The first detectable thin turbiditic silt appears above this (Sample 107-651A-40R-1, 102-103 cm), and the background dolomitic sediments show extensive, but patchy, diagenetic bleaching that frequently follows hairline cracks. The succession in this upper interval is less lithified and varies from red to yellow to pink (Sample 107-651A-38R-4, 15-2O cm), with sporadic black manganese-rich segregations less than $5 \mathrm{~mm}$ in size. Toward the top of this bright interval, colors are more subdued, i.e., greenish, grayish, and light yellowish-brown, with tiny black (mmsized), manganese-rich segregations (e.g., Section 107-651A-38R2; Pl. 1, Fig. 4). Lithified turbiditic ash layers are numerous, while the fine-grained sediment in the background remains sporadically dolomitic until $45 \mathrm{~m}$ above the basaltic basement, where nannofossil ooze and calcareous claystone are apparently unaltered. The nannofossil sediments above are more porous and less dense (Kastens, Mascle, Auroux, et al., 1987).

\section{Smear Slide Data}

The interlava sediment (Sample 107-651-50R-1, 40-68 cm) is composed of dolomite with traces of authigenic feldspar. The basal sediment above the recovered basalt is made up of mostly dolomite rhombohedra (2-20 $\mu \mathrm{m}$ in size), with minor clay minerals, altered volcanic glass, and black opaque metalliferous oxide grains (Samples 107-651A-41R-2, $97 \mathrm{~cm}$; -41R-2, $97 \mathrm{~cm}$; $41 \mathrm{R}-3,48 \mathrm{~cm}$; $-41 \mathrm{R}-5,68 \mathrm{~cm}$ ). One other smear slide (107-651A$41 \mathrm{R}-3,47 \mathrm{~cm}$ ) is made up of mainly authigenic feldspar and altered volcanic glass, with subordinate quartz, clay minerals, dolomite, micrite, and accessory minerals. Many of the individual dolomite rhombs are not euhedral and may have been corroded during diagenesis. Preserved nannofossils and planktonic foraminifers are absent from the dolomitized interval.

\section{X-Ray Diffraction}

Whole-rock X-ray diffraction (Table 1) indicates that the interlava sediment (Core 107-651A-50R) is composed of dolomite and quartz, with minor talc and illite and trace quantities of chlorite, feldspar, and kaolinite. The basal sediments above the igneous crust (Core 107-651A-41R) contain dolomite and quartz, with minor illite and traces of chlorite, anhydrite, and kaolinite. White and brown patches (diagenetic segregations) within one sample were examined separately. A brown patch contains quartz, dolomite, and feldspar, with traces of anhydrite, illite, and chlorite, while a white patch is composed of dolomite and quartz, with only minor illite and traces of feldspar and kaolinite. The brown patch apparently contains more abundant quartz, feldspar, and anhydrite than the white patch, but less detectable illite. Higher in the succession, dolomite and quartz dominate, followed by dolomite with subordinate illite and minor feldspar, chlorite, kaolinite, and mixed-layers clays (Table 1).

\section{Chemistry}

Twelve samples of metalliferous-looking sediments were analyzed from up to $40 \mathrm{~m}$ above the igneous basement (Section 107651A-39-41R; Table 3) as well as two samples of fine-grained dolomitic sediment from within the igneous basement (Core 107-651A-50R).

The major-element composition of the interlava sediments (Core 107-651-50R) lies within the range of values exhibited by the supra-lava sediments analyzed, with the exception of manganese, which is much lower $(0.41 \%-0.13 \%)$. Taken together, the supra-lava sediments are rich in $\mathrm{SiO}_{2}, \mathrm{Al}_{2} \mathrm{O}_{3}$ and $\mathrm{K}_{2} \mathrm{O}$, reflecting a dominantly terrigenous source (Table 3 ). $\mathrm{TiO}_{2}$ values exhibit little systematic variation and do not suggest any influx from the igneous basement. $\mathrm{CaO}$ values show no systematic variation up the succession. Apparently, $\mathrm{Fe}_{2} \mathrm{O}_{3}$ varies randomly, reaching $10.59 \%$ in Core $107-651 \mathrm{~A}-39 \mathrm{R}$, about $34 \mathrm{~m}$ above the igneous basement. $\mathrm{MgO}$ values are greatly enriched, relative to deep-sea clays (Turekian and Wedepohl, 1961) and range from $8.19 \%$ to $22.45 \%$. Manganese values are lowest in the sediments within the igneous basement $(0.14 \%$ and $0.32 \%)$, followed by high values in the basal supra-lava sediments (1.14\%). Above this, values vary randomly from $0.21 \%$ to $1.86 \%$.

The fine-grained dolomitic sedimentary rocks within the igneous basement are enriched in chromium and nickel, corresponding to the occurrence of the talc that was identified by Xray diffraction. Above the igneous basement, values of all the analyzed elements are within the range of deep-sea clay (Turekian and Wedepohl, 1961).

\section{Interpretation}

Before alteration, the basal sediment was calcareous and clay-rich nannofossil ooze, interbedded with mainly volcaniclastic and terrigenous silt turbidites higher in the succession. Apparently, ultramafic rocks were exposed on the seafloor locally, possibly resulting in erosion and accumulation of talc in deep-sea sediments that were later covered by basalt flows.

The sediments above the igneous basement were strongly altered during diagenesis, with segregation into darker $\mathrm{MnO}$-rich zones; brownish quartz-dolomite-feldspar-limonite-rich zones; and pale dolomite-quartz-rich zones. Earlier studies indicated that the mineralogy of the Pliocene successions in the Tyrrhenian Sea (Site 132, Leg 13; 37, Leg 42) remained constant during Pliocene time (Zemmels and Cook, 1973; Nesteroff, 1973; Chamley et al., 1978; Melieres et al., 1978) and was composed of mainly quartz, feldspar, illite, smectite, attapulgite, kaolinite, chlorite, and traces of mixed-layer clays. The sharply contrasting mineralogy between adjacent mottled zones points to diagenetic modifications of clay, which merits further study.

$\mathrm{X}$-ray studies (McKenzie et al., this volume) show that unusually magnesium-rich dolomite occurs in two discrete intervals: (1) as brightly colored sediments associated with the upper dolerite unit and (2) directly overlying the upper basaltic unit. According to shipboard pore-water data, the basal $40 \mathrm{~m}$ of the 


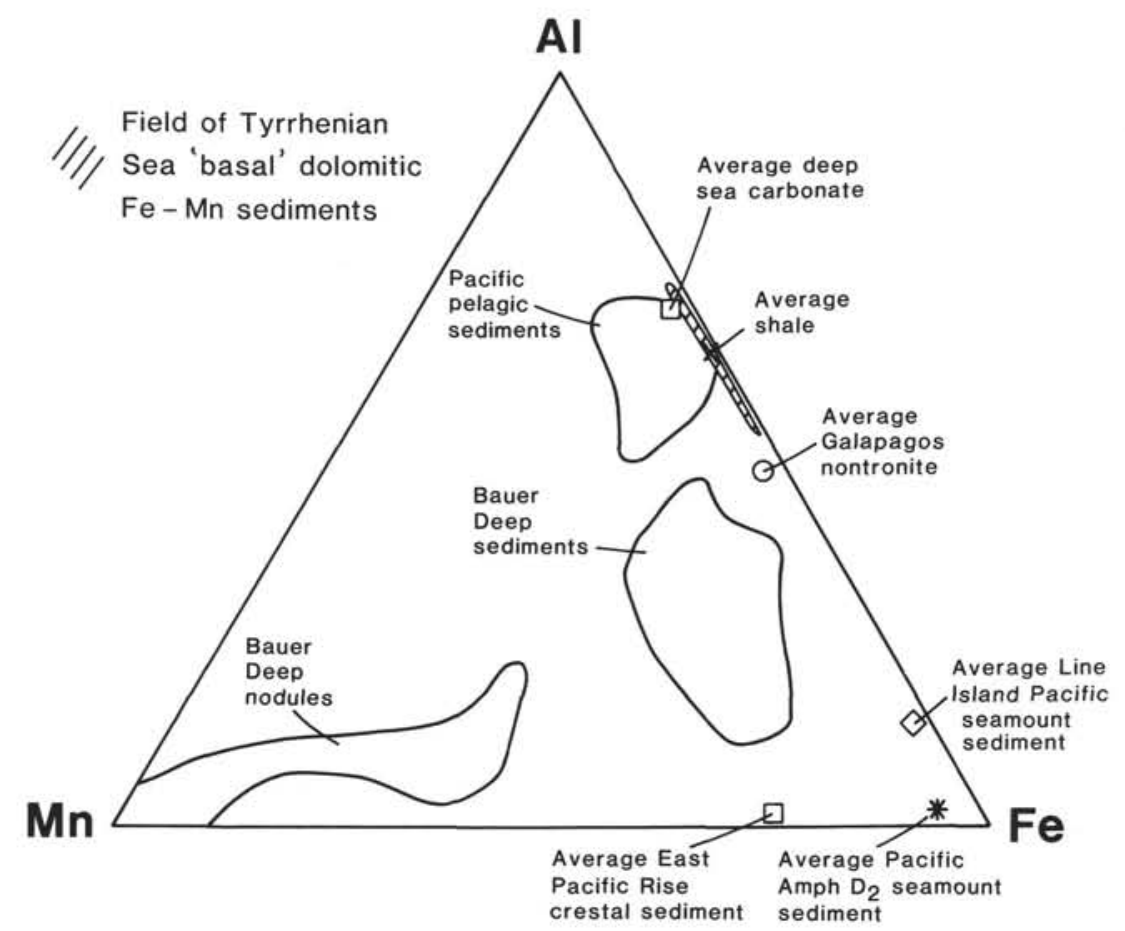

Figure 4. Triangular plot of $\mathrm{Al}, \mathrm{Fe}$, and $\mathrm{Mn}$ comparing the compositions of the ODP Leg 107 basal dolomitic and Fe-Mn sediments, with a range of contrasting sediments in the oceans.

succession is concentrated in magnesium, relative to calcium ions (up to $40 \%$ ) (Kastens, Mascle, Auroux, et al., 1987). This excess magnesium may have derived from ultramafic rocks, as cored at this site. Oxygen-isotopic data further indicate precipitation of the magnesium-rich dolomite from fluids at $44.5^{\circ} \mathrm{C}$, compared with an estimated in-situ temperature of $66.0^{\circ} \pm$ 3. $6^{\circ} \mathrm{C}$ (Kastens, Mascle, Auroux, et al.,1987).

Structures within the cores indicate a complex tectonic and diagenetic history. Primary bedding dips up to $30^{\circ}$ because of post-depositional tectonic tilting. A prominent Neptunian fissure (Sample 107-651-38R-1, 32-43 cm) resulted from dewatering while the sediment was still soft, possibly triggered by tectonic tilting. Later, the lithified dolomites were fractured by further tectonic activity. Warm (about $45^{\circ} \mathrm{C}$ ) "hydrotepid" fluids may have migrated along cracks at this stage, reducing and bleaching the adjacent dolomitic sediment, locally mobilizing iron and manganese, and corroding the dolomite rhombs.

\section{UPPER PLIOCENE SEDIMENTS OVERLYING THE GORTANI SEAMOUNT: SITE 655}

During Leg 107, the Gortani Ridge (a seamount near the base of the Sardinian margin) was found to comprise pillow basalt of high-titanium (within-plate type; Beccaluva et al., this volume). Dark, yellow brown, fine-grained sediments directly overlie aphanitic basalt with glassy chilled margins. Anomalous metalliferous-looking sediments persist about $20 \mathrm{~m}$ up the succession before passing into unaltered nannofossil ooze.

\section{Mineralogy}

Shipboard smear slide analysis of the basal sediment revealed dolomitic mudstone with nannofossils, planktonic foraminifers, traces of opaque minerals and volcanic glass. Two samples from higher in the succession (Core 107-655A-8R) are composed of less abundant dolomite, calcareous nannofossils, quartz, feldspar, clay, micrite, volcanic glass, zeolite, opaque oxide, and traces of sponge spicules, silicoflagellates, pellets, intraclasts, and calcite spar. Sediment from the top of the altered zone (Core 107-655A-8R) is clay-rich nannofossil ooze, with small amounts of quartz, feldspar, mica, calcite, micrite, and bioclasts.

X-ray diffraction of the basal samples (Table 1) reveals abundant calcite, subordinate quartz, and minor dolomite, illite, kaolinite, chlorite, and halite. The sample higher in the succession (Core 107-655A-6R) contains calcite and quartz, with subordinate feldspar, minor illite, kaolinite, chlorite, dolomite, and halite. The uppermost sample analyzed (Core 107-655A-5R) comprises calcite and quartz, with subordinate kaolinite and chlorite and minor illite, feldspar, dolomite, and halite.

\section{Geochemistry}

The major-element data (Table 4) show that the basal sediments are greatly enriched in $\mathrm{MgO}$, in keeping with the smear slide data. Values of the mainly lithogenous elements (silicon, aluminum, potassium, and titanium) increase up the succession. $\mathrm{Fe}_{2} \mathrm{O}_{3}$ values are similar to average shale, while those of $\mathrm{MnO}$ are low, approximately the levels in deep-sea clay (Turekian and Wedepohl, 1961).

The trace-element values all lie in the compositional range of average (calcareous) shale, with the exception of lead, which is slightly enriched to $96 \mathrm{ppm}$ (c.f., $20 \mathrm{ppm}$ in average shale).

\section{Interpretation}

Local dolomite formation in the basal sediment is attributed to low-temperature diagenetic alteration of pelagic sediment in contact with basalt. The calculated oxygen-isotopic equilibrium temperature is $14^{\circ} \mathrm{C}$ (McKenzie et al., this volume), comparable to the $13.2^{\circ} \mathrm{C}$ bottom-water temperature measured in-situ at Hole 655A (Kastens, Mascle, Auroux, et al., 1987). The upward increase in values of aluminum, titanium, magnesium, and potassium may reflect increased influx of terrigenous constituents, 
related to subsidence and sedimentation on the seamount after volcanism ended.

\section{COMPARISON OF DOLOMITIC SEDIMENTS WITH FE-MN SEDIMENTS}

Dolomitic, ferruginous, and manganiferous sediments, with little or no enrichment of trace elements, characterize the sediments above the igneous basement at each of the three sites cored in the Tyrrhenian Sea. Clasts of moderately lithified, pink, dolomitic sediment also were recovered from just above the basaltic basement at Hole 373A during Leg 42 (Bernoulli et al., 1978). This dolomite is composed of euhedral to subhedral crystals 5 to $20 \mu \mathrm{m}$ in size, together with a few silt-sized grains of quartz, pyrite, feldspar, and reddish-brown iron oxides. Spherical vugs are partly infilled with larger than average dolomite crystals and are interpreted as cavities produced by dissolution of planktonic foraminifers. X-ray diffraction revealed $79 \%$ dolomite, $6 \%$ quartz and feldspar, and $15 \%$ clay minerals. This dolomite has a $5 \mathrm{~mol} \%$ of excess calcium. Oxygen and carbon isotopic data suggest formation of the dolomite in normal deep marine waters. At the Leg 107 sites, the extent and thickness of the dolomitization and lithification is greatest in the Vavilov Basin (Site 651), intermediate in the Marsili Basin (Site 650), and least on the basaltic seamount (Site 655). The Site 651 sediments exhibit the most evidence of both early-stage (e.g., dewatering) and later-stage tectonic disturbance (e.g., brecciation and tilting), and also show more marked oxidation-reduction effects (e.g., bleaching, segregations of manganese and iron).

$\mathrm{X}$-ray diffraction and the compositions of lithogenous constituents (e.g., aluminum, zirconium) confirm a relatively constant influx to all three sites. However, Site 651 (Vavilov Basin) is richer in $\mathrm{MnO}$ and dolomite and is more lithified. In addition, Site 650 (Marsili Basin) is systematically enriched in $\mathrm{K}_{2} \mathrm{O}$, possibly reflecting influx from potassic volcanic rocks exposed in the Roman province on the Italian mainland.

Another marked difference is that at Site 650 magnesium and manganese correlate (Fig. 3), while at Sites 651 and 655, these elements do not. Iron varies independently of manganese and magnesium at each site.

\section{DISCUSSION: GENESIS OF THE DOLOMITIC AND FE-MN DEPOSITS}

\section{Hydrothermal Processes}

In the modern oceans, three main classes of hydrothermal sediments are known: sulfides (e.g., black smokers), silicates (e.g., Galapagos mound deposits), and oxides (e.g., East Pacific Rise crestal sediments). Primary oxide precipitates vary in composition from ferruginous to ferromanganiferous and manganiferous. Iron and Fe-Mn oxide sediments form mainly by oxidation of solutions and particles derived from ocean ridge sulfides (smokers), while manganiferous oxides commonly precipitate from lower temperature off-axis hydrothermal fluids (Boström and Peterson, 1969; Scott et al., 1974; Corliss, et al., 1977; Hekinian et al., 1983; Bonatti, 1983; Rona, 1984). Basal metalliferous sediments of hydrothermal origin from Southwest Pacific marginal basins are apparently less enriched in manganese and trace metals than their ocean ridge counterparts (Bonatti et al., 1979).

In the Mesozoic Tethys ocean, oxide sediments of varying composition accumulated in tectonic settings ranging from the Fe-Mn umbers of the Late Cretaceous Cyprus and Oman ophiolites, to more manganese-rich oxide sediments associated with late Triassic and Jurassic rift and continental margin settings (e.g., Antalya, southwestern Turkey) (Robertson and Boyle, 1983; Robertson and Fleet, 1986). The ophiolite-related oxide sediments exhibit field sedimentological evidence (e.g., fine parallel and micro-cross lamination, load-structures, grading) that confirms a primary depositional origin as chemical precipitates. In general, a primary precipitation origin is inferred for most modern and ancient oceanic metalliferous oxide sediment (e.g., East Pacific Rise crestal sediments; basal sediments drilled by DSDP in the Pacific ocean; see Rona et al., 1983).

The oceanic and ophiolite-related hydrothermal oxide sediments are relatively, but variably, enriched in iron, manganese, and trace metals (e.g., copper, nickel, lead, vanadium), but depleted in lithogenous constituents (e.g., aluminum, magnesium, potassium, zirconium; Fig. 4). However, not all the ophiolite-related hydrothermal metalliferous sediments are enriched in trace elements; ferruginous oxide sediments from within the lavas of the Arakapas transform fault of the Cretaceous Troodos ophiolite, for example, are depleted in lithogenous constituents (e.g., aluminum), but contain levels of trace metals (copper, zinc, nickel) similar to deep-sea clay (Robertson and Boyle, 1983).

Relative to shale and deep-sea clay, the Tyrrhenian Sea basal sediments are strongly enriched in manganese but show no marked enrichments in iron or in trace elements, nor depletion in aluminum, as in typical hydrothermal sediments (Fig. 4).

Leaching of basalt in heated seawater with high water/rock ratios causes extraction of magnesium to form smectite and chlorite, while heavy metals (iron, manganese) are leached (Bischoff and Dickson,1975; Mottl, 1983; Rosenbauer and Bischoff, 1983). Hydrothermal sediments are depleted in magnesium, and this, combined with the isotopic evidence (McKenzie et al., this volume), indicates that the Tyrrhenian Sea dolomites are unlikely to be direct hydrothermal precipitates.

\section{Seafloor Weathering of Basalt}

Alternatively, the magnesium enrichment resulted from lowtemperature weathering of igneous crustal rocks. One can add to the Tyrrhenian Sea dolomite examples an occurrence of wellindurated dolomite cored above basalt at the Guadalupe site of the Mohole in the Pacific (Riedel et al., 1961; Murata and Erd, 1964). Isotopic data suggest that this dolomite mainly formed in equilibrium, with normal marine waters at an ambient water temperature of about $5^{\circ} \mathrm{C}$ (Degens and Epstein, 1964). Other examples of dolomitization of sediments associated with oceanic basalts are summarizd by Garrison (1981). In one specific case, locally high magnesium contents in sediments overlying seamounts in the Pacific Line Islands (Jenkyns and Hardy, 1975) relate to erosion of underlying high-titanium basalt, rather than weathering. However, eroded basalt cannot be detected in the Tyrrhenian Sea basal sediments.

During long-term in-situ alteration of basalt on, or beneath, the seafloor (halmyrolysis), calcium and magnesium can be released (Hart, 1970), while studies of altered basalt and associated pelagic sediments (e.g., Pacific Lau Basin, Bertine, 1974) indicate that copper, magnesium nickel, cobalt, calcium, sodium, and silicon are removed from basalt relative to aluminum, while titanium, chromium, potassium, iron, and manganese are taken up.

During seafloor and/or sub-seafloor alteration (halmyrolysis), magnesium may have been selectively extracted from basalt and mobilized into adjacent sediments. However, this effect is not common, since most pelagic sediments overlying ocean crust and ophiolites have not been dolomitized. How then was up to $45 \mathrm{~m}$ of the pelagic sediment succession dolomitized in the Tyrrhenian Sea? Large-scale upward mobilization of magnesium implies extensive cool seawater circulation. Dolomitization is thickest and most advanced at Site 651 in the Vavilov Basin, where peridotites were cored at shallow depths (about $100 \mathrm{mbsf}$ ). These peridotites are interpreted as asthenosphere that protruded to high crustal levels near the continent-ocean boundary, which was also observed off the Atlantic Biscaye margin (Boillot et al., 
1980) and on Zagarbad Island in the Red Sea (Bonatti et al., 1981). Cool seawater circulation through peridotite may have supplied additional magnesium for the dolomitization of the overlying sediments.

How was the inferred circulation driven? The oxygen-isotopic data suggest that dolomite precipitated from cool to tepid seawater, and thus mainly before thick sediment accumulation in a regionally high heat-flow area $\left(85-162 \mathrm{~m} / \mathrm{W} / \mathrm{m}^{2}\right.$; Rehault et al., this volume) initiated markedly elevated interstitial-water temperatures. However, at Site 651 the determined isotopic temperature $\left(44.5^{\circ} \mathrm{C}\right)$ is near the calculated present estimated interstitial-water temperature (about $66^{\circ} \mathrm{C}$ ), suggesting that hydrothermal dolomitization could now be occurring.

\section{MODEL OF DOLOMITIZATION BY SUB-SEAFLOOR "HYDROTEPID" CIRCULATION}

A new model for the dolomitization is now outlined (Fig. 5) that the author hopes will be tested by future research. The basis of this model is that cool to tepid seawater was pumped into

A

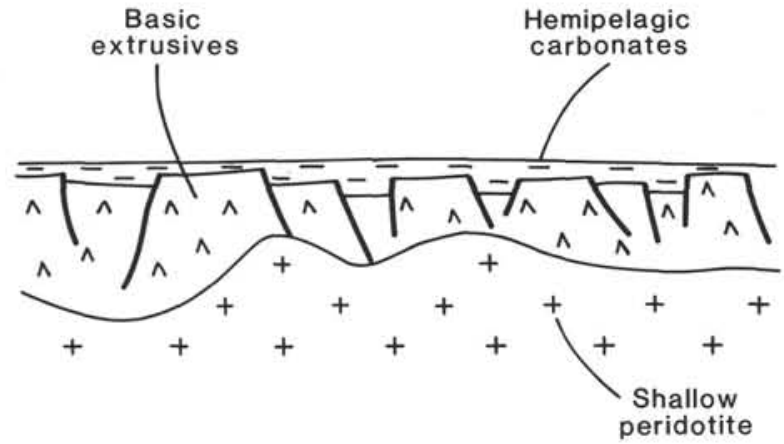

B

$\mathrm{Mg}, \mathrm{Fe} \& \mathrm{Mn}$ rich fluids expelled from basement

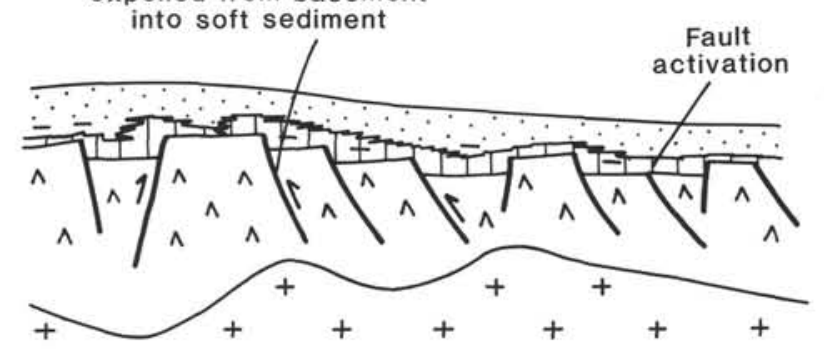

Lithified sediment fractured,

C

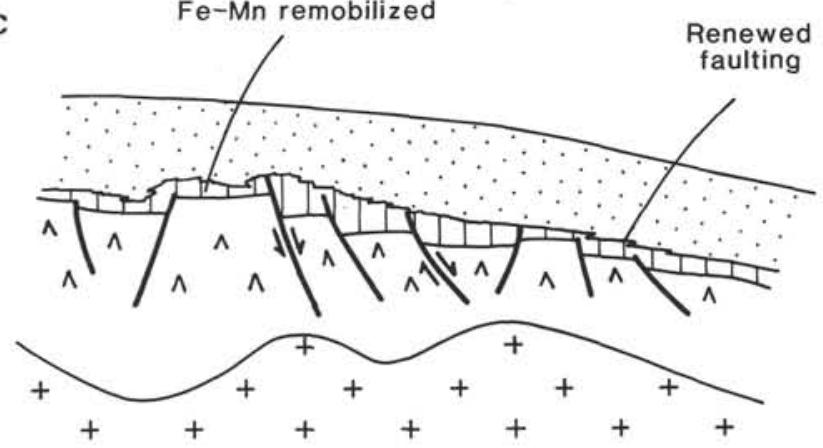

Figure 5. Sketch illustrating the hypothesis of "hydrotepid" circulation and dolomitization related to sub-seafloor alteration. the base of the sediment column during subsidence and deformation of the igneous basement.

The suggested scenario follows: First, the basal sediments at Site 651 were tilted as much as $30^{\circ}$ (measured apparent dips) before deposition of the overlying deep-sea sediments, which are nearly horizontal. At Site 650, tectonic instability is indicated by slumping of the basal sediments. The highly vesicular nature of Site 651 at Vavilov Basin and the Site 656 seamount lavas point to shallow-water eruption (less than $2500 \mathrm{~m}$ ), followed by rapid subsidence (estimated rates $=800 \mathrm{~m} / \mathrm{m}$.y.). Rifting migrated from Vavilov Basin to Marsili Basin during later Pliocene time, as the subduction zone was relocated farther southeast (Kastens, Mascle, Auroux, et al., 1987). Thus, rapid subsidence, tilting, faulting, and deformation of the underlying oceanic basement apparently took place during the initial period of overlying sedimentation. Consequently, cool to tepid seawater (i.e., "hydrotepid solutions"), charged with magnesium derived from long-term seawater interaction (halmyrolysis), was then expelled upward and/or laterally, reacted with, and replaced the muddy deep-sea carbonates above.

The manganese originally accumulated during genesis of the igneous basement, either by hydrogenous (i.e., slow) background accumulation from seawater and/or as a dispersed hydrothermal precipitate. During later sub-seafloor "hydrotepid" circulation, this manganese was dissolved and flushed from the igneous basement under mildly reducing conditions and reprecipitated within the base of the overlying, more oxidizing sediment column.

Dolomitization and manganese enrichment thus was complex and multistaged, and controlled by temperature, but also apparently by permeability, compaction, vertical and lateral fluid flow, Eh, and tectonic fracturing. In summary, dolomitization and manganese enrichment are attributed to the pumping of cool to tepid seawater out of the oceanic basement and related to tectonic movements not long after initial deposition of overlying deep-sea sediments.

Apparently, fault movements in the Vavilov Basin (Site 651) later fractured already lithified dolomite. By this stage, a thick sediment cover had accumulated. Reflecting the regionally high heat flow associated with young oceanic crust (presently 65-162 $\mathrm{m} / \mathrm{W} / \mathrm{m}^{2}$; Rehault et al., this volume), warmer fluids (about $45^{\circ} \mathrm{C}$ from isotopic data) continued to interact with the igneous basement, and later-stage hydrothermal fluids then moved though cracks in the dolomite, leaching iron and manganese, bleaching the adjacent dolomite, patchily redistributing iron and manganese, and altering clay minerals.

\section{CONCLUSIONS}

1. Basal dolomitic, iron and manganese sediments up to 45 $m$ thick occur at the base of Pliocene deep-sea sediment successions in the Tyrrhenian Sea at two basinal sites (Marsili Basin, Site 651; Vavilov Basin, Site 651) and on a basaltic seamount (Gortani Ridge, near the base of the Sardinian margin, Holes $655 \mathrm{~A}$ and $655 \mathrm{~B})$.

2. Interlava sediments in the Vavilov Basin (Site 651) contain serpentinite (talc) and are enriched in chromium and nickel, suggesting nearby exposure of ultramafic rocks. Asthenosphere peridotite was cored at about $100 \mathrm{mbsf}$ at this site.

3. After volcanism ended, the igneous basement was blanketed by fine-grained, clay-rich and calcareous deep-sea sediments that were compositionally similar to the overlying Pliocene cover. Relative potassium enrichment in the Vavilov Basin sediments may reflect influx from the Roman volcanic province on the Italian mainland.

4. After initial blanketing by deep-sea sediments, "hydrotepid" fluids enriched in magnesium reacted with and dolomitized the base of the overlying sediment column. 
5. Dolomitization was thickest and most intense in the Vavilov Basin (Site 651), where asthenosphere peridotite was cored at shallow depths. Slow, cool seawater circulation through peridotite probably released any excess magnesium.

6. The main constraint on dolomitization was the flushing of magnesium-rich "hydrotepid" solutions from the oceanic basement, related to sediment compaction and to cooling, tilting, subsidence, and deformation of the oceanic basement.

7. The enrichment of manganese in the basal sediments is attributed to upward flushing of dispersed, originally hydrogenous and/or hydrothermal manganese upward from the igneous basement during this "hydrotepid" circulation.

8. Tectonic movements in the Vavilov Basin apparently fractured already lithified dolomite at a later stage, and reducing (? hydrothermal) fluids locally remobilized iron and manganese, altered clay minerals, and corroded dolomite rhombs. Dolomitization thus was complex, multiphased, and may still be continuing.

\section{ACKNOWLEDGMENTS}

I thank G. Fitton, G. R. Angell, and D. James for assistance with the X-ray fluorescence and X-ray diffraction analyses. The manuscript benefitted from the comments of two anonymous reviewers. Judy McKenzie kindly supplied a copy of her chapter (in this volume) dealing with the dolomitic sediments.

\section{REFERENCES}

Bernoulli, D., Garrison, R. E., and McKenzie, J., 1978. Petrology, isotope chemistry and origin of dolomite and limestone, associated with basaltic breccia, Hole 373A, Tyrrhenian Basin. In Hsü, K., J., Montadert, L., et al., Init. Repts. DSDP, 42(Pt. 1): Washington (U.S. Govt. Printing Office, 541-588.

Bertine, K. K., 1974., Origin of Lau Basin sediment. Geochim. Cosmochim. Acta, 38:629-640.

Bischoff, J. K., and Dickson, F., 1975. Seawater-basalt alteration at $200^{\circ} \mathrm{C}$ and 500 bars: implications for origin of seafloor heavy-metal deposits and regulation of seawater composition. Earth Planet. Sci. Lett., 25:385-397.

Boillot, G., Grimaud, S., Mauffret, A., Mougenot, D., Mergoil-Daniel, J., Kornprobst, J., and Torrent, G., 1980. Ocean-continent boundary off the Iberian margin: a serpentinite diapir west of the Galicia Bank. Earth Planet. Sci. Lett., 48:23-34.

Bonatti, E., 1983. Hydrothermal metal deposits from the oceanic rifts: a classification. In Rona, P. A. and (Eds.), Hydrothermal Processes at Seafloor Spreading Centers: New York and London (Plenum Press), NATO Conf. Ser., 491-502.

Bonnatti, E., Kolla, V., and Moore, W. S., 1979. Metallogenesis in marginal basins: Fe-rich basal deposits from the Phillipine Sea. Mar Geol., 32:21-37.

Bonatti, E., Hamlyn, P. R., and Ottonello, G., 1981. The upper mantle beneath a young ocean rift: peridotites from the island of Zabargad, Red Sea. Geology, 9:474-479.

Boström, K., and Peterson, M.N.A., 1969. The origin of aluminumpoor ferromanganoan sediments in areas of high heat flow on the East Pacific Rise. Mar. Geol., 32:21-37.

Chamley, H., Dunoyer de Segonzac, G., and Melières, F., 1978. Clay minerals in Messinian sediments of the Mediterranean Sea. In Hsü, K. J., Montadert, L., et al., Init. Repts. DSD"P, 42(Pt.1): Washington (U.S. Govt. Printing Office), 388-395.

Corliss, J. B., Lyle, M., Dymond, J., and Crane, K., 1977. The chemical of hydrothermal mounds near the Galapagos Rift. Earth Planet. Sci. Lett., 40:12-24.

Degens, E. T., and Epstein, S., 1964. Oxygen and carbon isotopic ratios in existing calcites and dolomites from recent and ancient sediments. Geochim. Cosmochim. Acta, 28:23-44.

Dick, H.J.B., 1980. Vesicularity of the Shikoku Basin basalt: a possible correlation with the anomalous depth of backarc basins. In Klein, G., Kobayashi, K., et al., Init. Repts. DSDP, 58: Washington (U.S. Govt. Printing Office), 895-904.

Garrison, R. E., 1981. Diagenesis of oceanic carbonate sediments: a review of the DSDP perspective. In Warme, J. E., Douglas, R. G.
Winterer, E. L. (Eds.), The Deep Sea Drilling Project: A Decade of Progress. Soc. Econ. Palentol. Mineral., Spec. Publ., 32:181-207.

Hart, R., 1979. Chemical exchange between seawater and deep-ocean basalts. Earth Planet. Sci. Lett., 9:269-279.

Hekinian, R., Renard, V., Cheminee, J. L., 1983. Hydrothermal deposits on the East Pacific Rise near $13^{\circ} \mathrm{N}$ : geological setting and distribution of active sulfide vents. In Rona, P., Boström, K., Laubier, L., and Smith, K. J., Hydrothermal Processes at Seafloor Spreading Centres: New York and London (Plenum Press), NATO Conf. Ser. 4, Mar. Sci., 12:571-594.

Jenkyns, H. C.,, and Hardy, R., G., 1975. Basal iron-titanium-rich sediments from Hole 315A (Line Islands, Central Pacific). In Schlanger, S. O., Jackson, E. D., et al., Init. Repts. DSDP, 33: Washington (U.S. Govt. Printing Office), 833-836.

Jones, J. G., 1969. Pillow basalts as depth indicators. Am. J. Sci., 267: 181-195.

Kastens, K. A., Mascle, J., and Shipboard Scientific Party, in press. ODP Leg 107 in the Tyrrhenian Sea: insights into passive margin and backarc basin evolution. Bull. Geol. Soc. Am.

Kastens, K. A., Mascle, J., Auroux, C., et al., 1987. Proc. ODP, Init. Repts., 107: College Station, TX (Ocean Drilling Program).

Melières, F., Chamley, H., Coumes, F., and Rouge, P., 1978. X-ray mineralogical studies, Leg 42A, DSDP, Mediterranean Sea. In Hsü, K. J., Montadert, L., et al., Init. Repts. DSDP, 42(Pt. 1): Washington (U.S. Govt. Printing Office), 361-384.

Mottl, M. J., 1983. Hydrothermal processes at seafloor spreading centres: applications of basalt-seawater experimental results. In Rona, P., Boström, K., Laubier, L., and Smith, K. J., Hydrothermal Processes at Seafloor Spreading Centres: New York and London (Plenum Press), NATO Conf. Ser. 4, Mar. Sci., 12:199-224.

Murata, K. J., and Erd, R. C., 1964. Composition of sediments from the experimental Mohole Project (Guadalupe Site). J. Sediment. Petrol., 34:633-655.

Nesteroff, W. D., 1973. Distribution of fine-grained sediment component in the Mediterranean. In Ryan, W.B.F., and Hsü, K. J., et al., Init. Repts. DSDP, 13: Washington (U.S. Govt. Printing Office), 666-669.

Riedel, W. R., Ladd, A. S., Tracey, J. I., Jr., and Bramlette, U. N., 1961. Preliminary drilling phase of the Mohole Project II. Summary of coring operations. AAPG Bull., 45:1793-1798.

Robertson, A.H.F., and Boyle, J. F., 1983. Tectonic setting and origin of metalliferous sediments in the Mesozoic Tethys ocean. In Rona, P. A., Boström, K., Laubier, L., and Smith, K. J., Hydrothermal Processes at Seafloor Spreading Centres: New York and London (Plenum Press), NATO Conf. Ser. 4, Mar. Sci., 12:595-663.

Robertson, A.H.F., and Fleet, A. J., 1986. Geochemistry and paleoceanography of metalliferous and pelagic sediments from the Late Cretaceous Oman ophiolite. Mar. Petrol. Geol., 3:315-337.

Rona, P. A., 1984. Hydrothermal mineralization at seafloor spreading centres. Earth Sci. Rev., 20:1-104.

Rona, P. A., Boström, K., Laubier, L., and Smith, K. J., 1983. Hydrothermal Processes at Seafloor Spreading Centres: New York and London (Plenum Press), NATO Conf. Ser. 4, Mar. Sci., 12.

Rosenbauer, R. J., and Bischoff, J. L., 1983. Uptake and transport of heavy metals by heated seawater: a summary of the experimental results. In Rona, P. A., Boström, K., Laubier, L., and Smith, K. J., Hydrothermal Processes at Seafloor Spreading Centres: New York and London (Plenum Press), NATO Conf. Ser. 4, Mar. Sci., 12:177198.

Scott, M. R., Scott, R. B., Rona, P. A., Butler, L. W., and Nalwalk, A. J., 1974. Rapidly accumulating manganese deposits from the median valley of the Mid-Atlantic Ridge. Geophys. Res. Lett., 1:355358.

Turekian, K. K., and Wedepohl, K. H., 1961. Distribution of the elements in some major units of the earth's crust. Bull. Geol. Soc. Am., 72:175-191.

Zemmels, I., and Cook, H. E., 1973. X-ray mineralogy of selected samples from the seafloor of the Northeast Atlantic and Mediterranean Sea. In Ryan, W.B.G., Hsü, K. J., et al., Init. Repts. DSDP, 13: Washington (U.S. Govt. Printing Office), 605-665.

Date of initial receipt: 28 August 1987

Date of acceptance: 2 December 1988

Ms 107B-126 


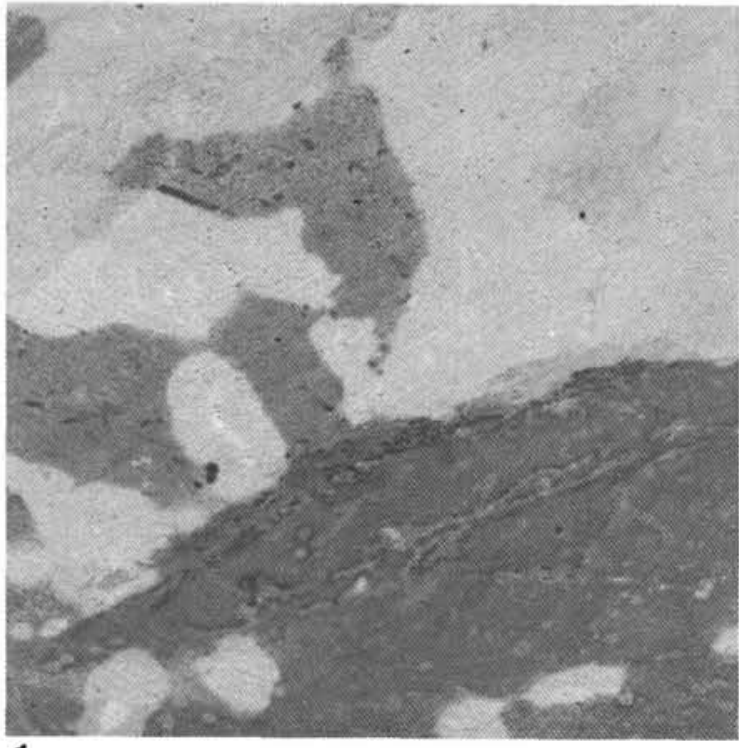

1

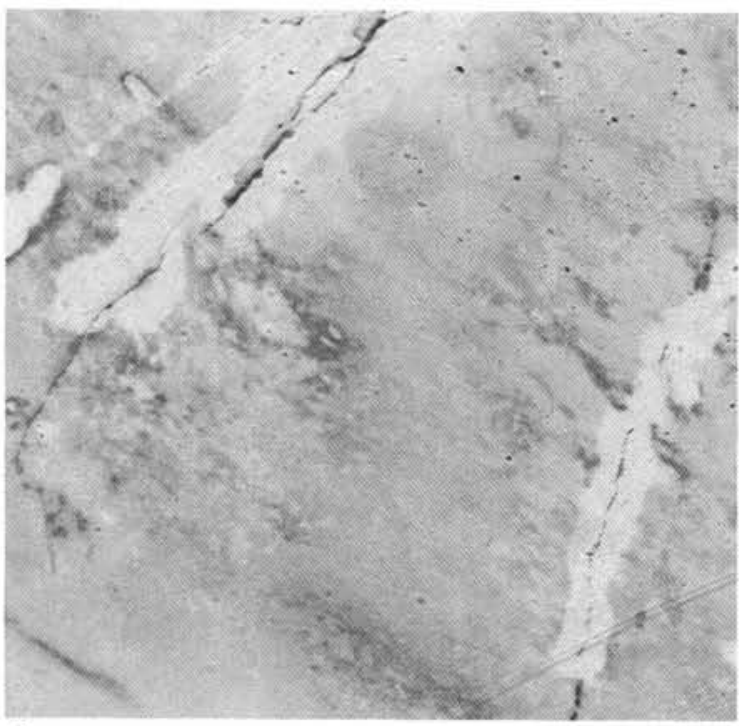

3
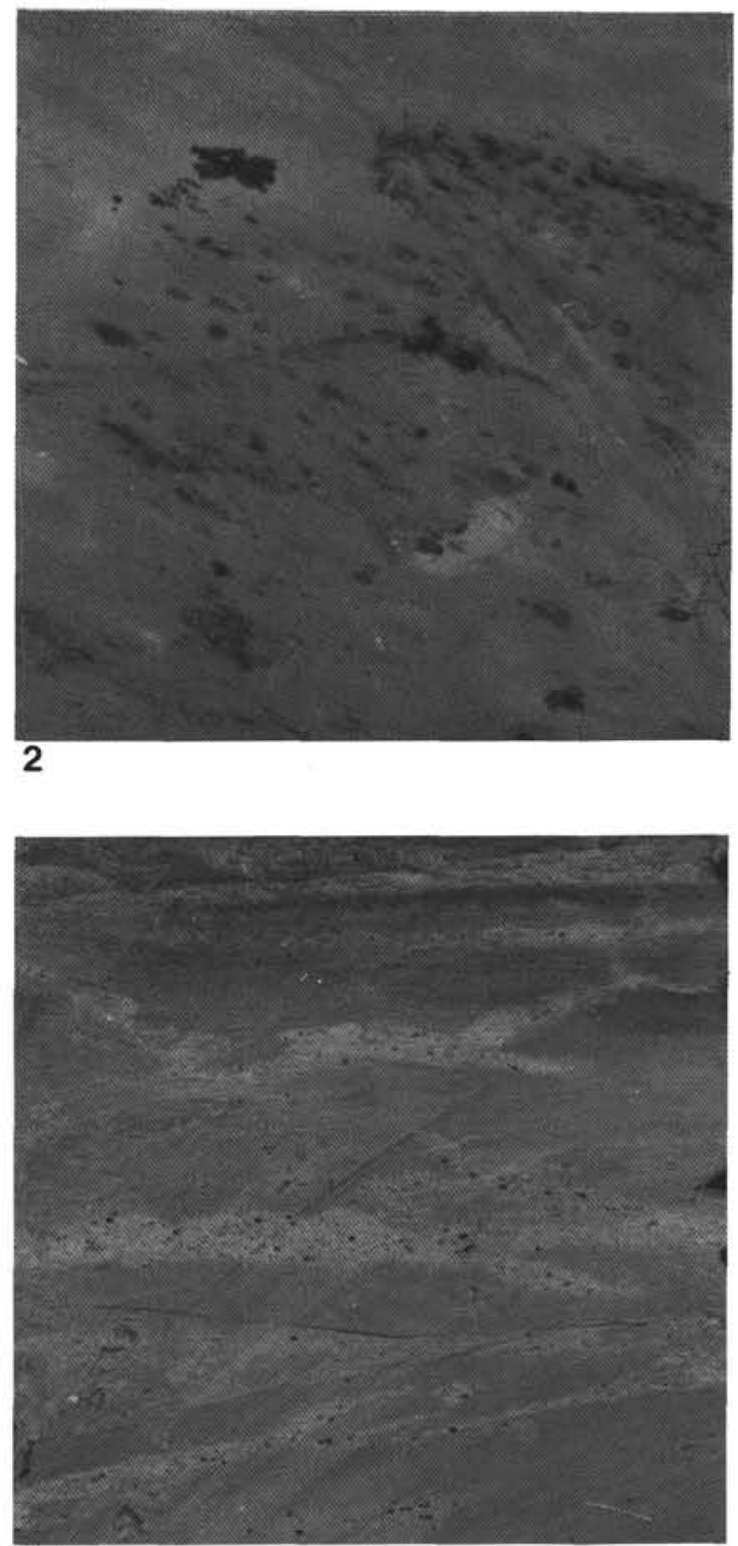

4

Plate 1. Core photographs illustrating the basal and intrabasement dolomitic and Fe-Mn sediments cored at Site 651 in the Vavilov Basin. 1. Pinkish dolomitic sediment patchily reduced to a grayish color (107-651A-39R-5, 20.0-24.8 cm). 2. Typical dark reddish metalliferous dolomite with dendritic Mn-oxide segregations (107-651-39R-1, 89.3-94.0 cm). 3. Bleaching (reduction) concentrated along cracks in nearly massive dolomite (107651A-38R-5, 58.1-63.5 cm). 4. Less lithified, stratigraphically higher, burrowed clay-rich sediments stained by Fe-Mn oxides, with abundant finegrained dolomite (107-651A-37R-5, 74.9-79.1 cm). 